\title{
Development of a Fluorinated Analogue of Erlotinib for PET Imaging of EGFR Mutation-Positive NSCLC
}

\author{
Ofer Shamni, Hilbert Grievink, Batel Itamar, Eyal Mishani, Galith Abourbeh (1)
}

Cyclotron/Radiochemistry/MicroPET Unit, Hadassah Hebrew University Hospital, Hadassah Medical Organization, 91120, Jerusalem, Israel

\begin{abstract}
Purpose: Positron emission tomography (PET) using $\left[{ }^{11} \mathrm{C}\right]$ erlotinib identifies non-small cell lung carcinoma (NSCLC) tumors with activating mutations in the epidermal growth factor receptor $\left(E G F R_{m}\right)$. The short half-life of $\mathrm{C}-11$, however, limits its clinical utility to centers with a nearby cyclotron. We therefore developed a F-18-labeled analogue of erlotinib for imaging EGFR NSCLC.

Procedures: 6-O-Fluoroethylerlotinib (6-O-FEE) was synthesized and its anti-proliferative activity was tested using human NSCLC cell lines. The F-18-labeled compound, 6-O- $\left[{ }^{18} \mathrm{~F}\right] \mathrm{FEE}$, was obtained in a two-step synthesis, and PET acquisitions were carried out following its injection to NSCLC tumor-bearing mice.

Results: In vitro, 6-O-FEE had maintained the selectivity and potency of erlotinib to EGFR $\mathrm{R}_{\mathrm{m}}$ NSCLC. In vivo, 6-O-[ $\left.{ }^{18} \mathrm{~F}\right] \mathrm{FEE}$ accumulation in EGFR $\mathrm{m}_{\mathrm{m}}$ tumors at $60 \mathrm{~min}$ after injection was 2and 3.3-fold higher than in erlotinib-resistant or erlotinib-insensitive tumors, respectively.

Conclusions: 6-O-[ $\left.{ }^{18} \mathrm{~F}\right] \mathrm{FEE}$ holds promise for imaging $\mathrm{EGFR}_{\mathrm{m}}$ NSCLC, warranting further investigation to fully explore its potential for stratifying NSCLC patients.
\end{abstract}

Key words: EGFR, NSCLC, Imaging, PET, Erlotinib, Fluorine-18, 6-O-[ $\left.{ }^{18} \mathrm{~F}\right] \mathrm{FEE}, \mathrm{TKI}$

\section{Introduction}

The epidermal growth factor receptor (EGFR) is overexpressed in over $60 \%$ of non-small cell lung carcinoma (NSCLC) tumors, and its mutational status in advanced/ metastatic NSCLC has both a prognostic value and a therapeutic impact [1-5]. The predominant activating mutations in this receptor, i.e., exon 19 deletions and the L858R point mutation in exon 21 , are associated with responsiveness to EGFR tyrosine kinase inhibitors (TKIs)

Electronic supplementary material The online version of this article (https:// doi.org/10.1007/s11307-018-1286-8) contains supplementary material, which is available to authorized users.

Correspondence to: Galith Abourbeh; e-mail: abourbehg@hadassah.org.il
$[6,7]$. These sensitizing mutations are found in $10-15 \%$ of Caucasian patients with NSCLC and in up to $50 \%$ of Asian patients [6-9].

To date, optimal first-line treatment of EGFR mutationpositive $\left(\mathrm{EGFR}_{\mathrm{m}}\right)$ NSCLC comprises any of the approved EGFR TKIs, including gefitinib, erlotinib, and afatinib [6, 7, 10, 11]. Recently, the third-generation EGFR TKI, osimertinib, has also been approved for the first-line treatment of EGFR $\mathrm{m}_{\mathrm{m}}$ NSCLC [12]. These EGFR TKIs offer a longer progression-free survival (PFS), higher response rate (RR), and reduced side effects, compared to standard chemotherapy $[6,7]$. Conversely, NSCLC patients whose tumors do not harbor sensitizing EGFR mutations do not benefit from EGFR TKI therapy and should be treated with chemotherapy, specific inhibitors of other oncoproteins, or immune checkpoint inhibitors $[6,10,11,13]$. Since 
activating EGFR mutations are present in only a subset of NSCLC patients, current indications recommend that the mutational status of this receptor is examined prior to therapy $[6,7,10,14]$.

Typically, EGFR mutation testing in NSCLC is carried out using tumor tissue biopsies or fine-needle aspirates, which entail invasive procedures and provide no information regarding the presence of distant metastases and/or their molecular characteristics [5, 7]. Additionally, EGFR mutation analysis using tissue/cytology specimens is not always feasible, often due to suboptimal tumor DNA quantity and/or quality for genomic characterization $[6-8,15,16]$. Consequently, different non-invasive approaches which provide systemic information have been explored for obtaining molecular information concerning the EGFR's mutational status in NSCLC patients, including liquid biopsies [4, 17, 18], analysis of computed tomography-based radiomic features [19], and the use of radiolabeled TKIs for positron emission tomography (PET) molecular imaging (MI) [20-23].

In this regard, the use of $\left[{ }^{11} \mathrm{C}\right]$ erlotinib-PET for detecting EGFR $_{\mathrm{m}}$ NSCLC and metastases has been reported both in animal models and in human subjects [17, 20, 24-32], offering a non-invasive and sensitive tool for assessing the mutational status of the EGFR. Nonetheless, the relatively short half-life of $\mathrm{C}-11(\sim 20 \mathrm{~min})$ poses a challenge to the wider clinical application of $\left[{ }^{11} \mathrm{C}\right]$ erlotinib-PET, since it limits its use to centers with a nearby cyclotron, calling for the research and development of novel EGFR TK PET probes which are labeled with longer-lived isotopes, such as F-18 [22].

To extend the clinical impact of erlotinib-PET for detecting $\mathrm{EGFR}_{\mathrm{m}}$ NSCLCs, we have designed, synthetized, and labeled with F-18 the erlotinib analogue, 6-Ofluoroethylerlotinib (6-O-FEE) (Fig. 1). The synthesis and anti-proliferative effect of 6-O-FEE in human NSCLC cell lines, as well as the stability of $6-\mathrm{O}-\left[{ }^{18} \mathrm{~F}\right] \mathrm{FEE}$ in vivo and its ability to identify $\mathrm{EGFR}_{\mathrm{m}}$ NSCLC in tumor-bearing mice, are described herein.

\section{Materials and Methods}

\section{General}

Insulin, transferrin, HEPES, and sodium pyruvate were purchased from Biological Industries (BI) (Kibbutz Beit

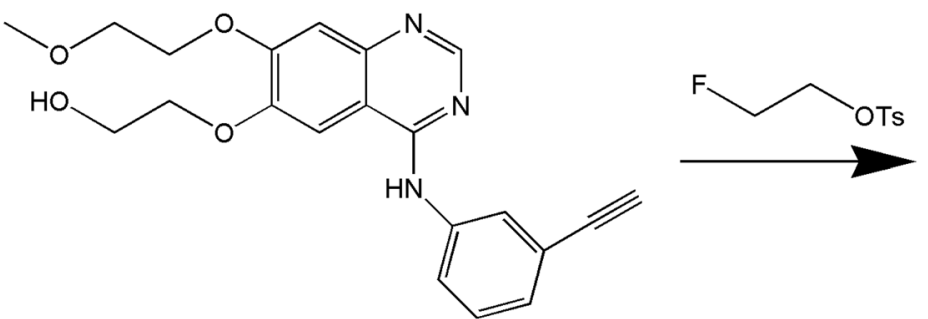

Haemek, Israel). Sodium selenite, hydrocortisone, ethanolamine, O-phosphorylethanolamine, 3,3',5-Triiodo-Lthyronine $\left(\mathrm{T}_{3}\right)$, bovine serum albumin (BSA), and $N, N$ dimethylformamide (DMF) were purchased from SigmaAldrich (Rehovot, Israel). Captisol ${ }^{\circledR}$ was obtained from CyDex Pharmaceuticals Inc. (KS, USA).

Hsd: Athymic Nude-Fox1nu mice (male, $4-5$ weeks) and BALB/c olaHsd mice (male, 9-10 weeks) were obtained from Envigo (Rehovot, Israel). All animal studies were conducted under protocol number MD-13-13833-5, approved by the Animal Research Ethics Committee of the Hebrew University of Jerusalem, and in accordance with its guidelines. Animals were acclimated for at least 3 days prior to their inoculation with tumor cells. Animals were routinely kept in 12-h light/dark cycles and provided with food and water ad libitum.

\section{Instrumentation}

See the description in the electronic supplementary material (ESM).

\section{Synthesis of 6-O-Fluoroethylerlotinib (6-O-FEE) Standard}

See the description in the ESM.

\section{Synthesis of 6-O- $\left[{ }^{18} \mathrm{~F}\right]$ Fluoroethylerlotinib (6-O- ${ }^{18}$ F]FEE)}

$\left[{ }^{18} \mathrm{~F}\right]$ Fluoride ion was produced by the ${ }^{18} \mathrm{O}(\mathrm{p}, \mathrm{n}){ }^{18} \mathrm{~F}$ nuclear reaction using $3 \mathrm{ml}$ enriched $\left[{ }^{18} \mathrm{O}\right]$ water $(98 \%$ isotopic purity, Rotem Industries, Mishor Yamin, Israel) as a target and an IBA 18/9 cyclotron. Thereafter, $\left[{ }^{18} \mathrm{~F}^{-} \mathrm{F}^{-} /\left[{ }^{18} \mathrm{O}\right] \mathrm{H}_{2} \mathrm{O}\right.$ was transferred to the module, loaded onto an anion exchange column (30PS- $\mathrm{HCO}_{3}$, Macherey Nagel, Düren, Germany), and eluted with $0.5 \mathrm{ml}$ of $\mathrm{K}_{2} \mathrm{CO}_{3}$ solution $(8 \mathrm{mg} / \mathrm{ml})$ to the reaction vessel. After addition of Kryptofix-2.2.2 (15 mg dissolved in $1 \mathrm{ml} \mathrm{MeCN}$, Merck, Darmstadt, Germany), azeotropic removal of water and $\mathrm{MeCN}$ was achieved by heating the reactor to $82{ }^{\circ} \mathrm{C}$ under a stream of argon (2.4 bar) and reduced pressure for $2 \mathrm{~min}$, yielding a pressure of 0.2 bar inside the reactor. This was

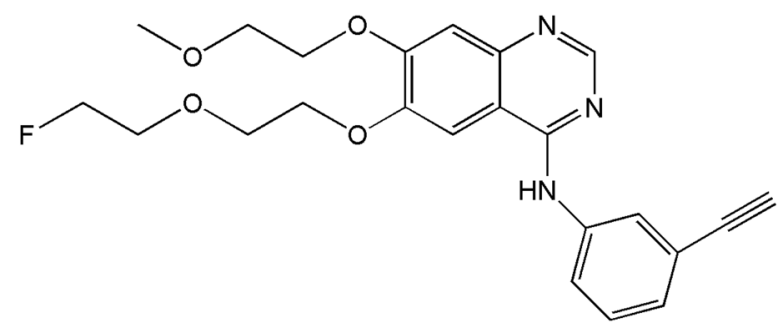

Fig. 1. Synthesis of 6-O-fluoroethylerlotinib (6-O-FEE) reference standard. 
followed by an additional $3.5 \mathrm{~min}$ under $102{ }^{\circ} \mathrm{C}$ and reduced pressure, to yield a pressure of 0.04 bar inside the reactor.

Reagent vials were loaded onto the GE TRACER Lab $\mathrm{Fx}_{\mathrm{FN}}$ module as follows: vial $1(\mathrm{~V} 1)$, potassium carbonate $(0.5 \mathrm{ml}$ of a $8 \mathrm{mg} / \mathrm{ml}$ solution, Sigma-Aldrich); V2, Kryptofix-2.2.2 (15 mg dissolved in $1 \mathrm{ml} \mathrm{MeCN}$ ); V3, 11$13 \mathrm{mg}$ ethylene 1,2-bis(tosylate) dissolved in $0.75 \mathrm{ml}$ dry $\mathrm{MeCN}$; V4, $1 \mathrm{ml}$ of MeCN; V7, $1.8 \mathrm{ml}$ of ethanol; V8, $4 \mathrm{ml}$ of $\mathrm{H}_{2} \mathrm{O}$ (HPLC grade); SPE vial, $24 \mathrm{ml}$ of HPLC water; and collection vial, $12 \mathrm{ml}$ of $0.9 \%$ sodium chloride solution for injection. The Fx-FDOPA module was prepared as follows: $\mathrm{V} 1$, desmethylerlotinib $(11 \mathrm{mg})$ dissolved in $0.6 \mathrm{ml}$ dry DMF; V2, $1.5 \mathrm{ml}$ of acetate buffer $(0.1 \mathrm{M}, \mathrm{pH} 3.8$; MeCN (6:4)) and $3 \mathrm{mg}$ of $\mathrm{NaH}$, directly added to the reactor and flushed with argon.

6-O- $\left[{ }^{18} \mathrm{~F}\right]$ Fluoroethylerlotinib was obtained in a fully automated two-step synthesis, as depicted in Fig. 2, using an automated GE TRACER Lab $\mathrm{Fx}_{\mathrm{FN}}$ module coupled to a Fx-FDOPA module (Suppl. Figs. 1 and 2; see ESM). In the first step, $\left[{ }^{18} \mathrm{~F}\right]$ fluoroethyltosylate was obtained from ethylene 1,2-bis(tosylate), as previously published [33], and in the second step, it was further reacted with desmethylerlotinib to yield the desired product. In brief, a solution of ethylene 1,2-bis(tosylate) (ABX, Radeberg, Germany, 11-13 mg) dissolved in anhydrous $\mathrm{MeCN}$ $(750 \mu \mathrm{l})$ was added to dried $\left[{ }^{18} \mathrm{~F}\right]$ fluoride. The reaction vessel was heated to $120{ }^{\circ} \mathrm{C}$ while stirring for $10 \mathrm{~min}$ and thereafter cooled to $50{ }^{\circ} \mathrm{C}$. The ensuing $\left[{ }^{18} \mathrm{~F}\right]$ fluoroethyltosylate was further diluted with $1 \mathrm{ml}$ $\mathrm{MeCN}$, filtered, and transferred to a second reactor (FxFDOPA module) that was pre-stirred and heated under argon stream for $5 \mathrm{~min}$ at $40{ }^{\circ} \mathrm{C}$, containing $11 \mathrm{mg}$ of $6-\mathrm{O}$ desmethylerlotinib dissolved in $0.6 \mathrm{ml}$ of DMF and 3-4 mg of $\mathrm{NaH}$. The combined reaction mixture was then heated to $90{ }^{\circ} \mathrm{C}$ and stirred for $10 \mathrm{~min}$ in a sealed reactor, cooled to $60{ }^{\circ} \mathrm{C}$ and diluted with $1.5 \mathrm{ml}$ of acetate buffer $(0.1 \mathrm{M}, \mathrm{pH}$ 3.8; $\mathrm{MeCN}(6: 4)$ ). The crude solution was then filtered and purified on a semi-preparative $\mathrm{C} 18$ column $(5 \mu \mathrm{m}, 10 \mathrm{~mm} \times$ $250 \mathrm{~mm}$, Luna, Phenomenex, Torrance, CA, USA), equipped with a UV detector operated at $254 \mathrm{~nm}$ and a radio-detector, using the aforementioned acetate buffer $(\mathrm{MeCN})$ as eluent, at a flow rate of $4 \mathrm{ml} / \mathrm{min}$. The final product (retention time at $14 \mathrm{~min}$ ) was collected in a solid- phase extraction vial and was further diluted with $24 \mathrm{ml}$ of water (HPLC grade). The obtained solution was then loaded onto a C18-Plus Sep-Pak cartridge (Waters Corporation, Milford, MA, USA), pre-activated with $5 \mathrm{ml}$ ethanol and $10 \mathrm{ml}$ of water (HPLC grade), and washed with an additional $4 \mathrm{ml}$ of water. The product was subsequently eluted using $1.8 \mathrm{ml}$ ethanol and was further diluted with $18.2 \mathrm{ml}$ of isotonic saline.

\section{Quality Control Analysis of 6-O- $\left[{ }^{18} \mathrm{~F}\right] \mathrm{FEE}$}

See the description in the ESM.

\section{Cell Culture}

See the description in the ESM.

\section{Inhibition of Cell Growth}

QG56 (3000 cells), HCC827, NCI-H3255 (5000 cells), and NCI-H1975 (7000 cells) were seeded and cultured in 96well plates. Twenty-four to $48 \mathrm{~h}$ after seeding, cells were treated with increasing concentrations $(0-100 \mu \mathrm{M})$ of erlotinib (Cayman Chemical, Ann Arbor, MI, USA) or 6O-FEE. The media containing the inhibitors $(0.05 \%$ DMSO, $0.1 \%$ ethanol) were freshly prepared and replaced every $24 \mathrm{~h}$. Following $72 \mathrm{~h}$ of treatment, cell growth was determined by methylene blue assay [34]. The median inhibitory concentrations $\left(\mathrm{IC}_{50}\right)$ for cell growth of each cell line were calculated using GraphPad Prism 5.0 software. Experiments were repeated three to four times for each cell line, with three to six replicates per tested concentration.

\section{NSCLC Xenografts}

Mice were anesthetized with isoflurane (1-2\% in oxygen) and injected subcutaneously (s.c.) in the right front flank with a suspension of five million cells in medium containing Matrigel (BD Biosciences, Beit Haemek, Israel, $20 \%(v / v))$.

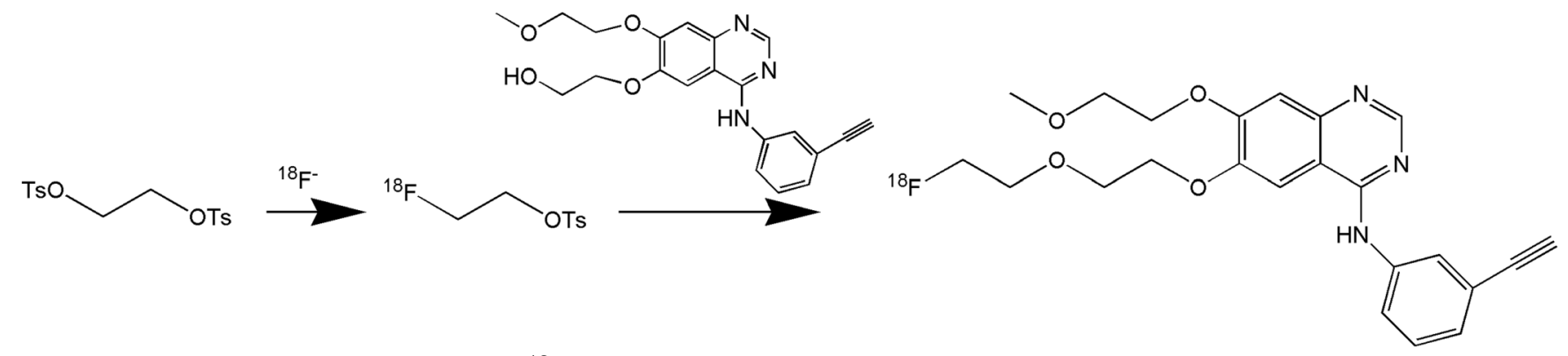

Fig. 2. Two-step radiosynthesis of 6-O- $\left[{ }^{18} \mathrm{~F}\right] \mathrm{FEE}$. 


\section{MicroPET/CT Studies}

Three weeks after inoculation of cells, tumor-bearing mice (32.3 $\mathrm{g}(n=38))$ were anesthetized with isoflurane and kept at $38{ }^{\circ} \mathrm{C}$ using a heating pad. After performing a CT attenuation-correction scan, PET acquisitions were carried out using an Inveon ${ }^{\text {TM }}$ MM PET-CT scanner (Siemens Medical Solutions, USA). One-hour PET acquisitions were started simultaneously to 6-O-[ $\left.{ }^{18} \mathrm{~F}\right] \mathrm{FEE}$ injection via the lateral tail-vein $(6.8 \pm 1.0 \mathrm{MBq}(n=38))$. Subsequently, mice were maintained in the same position and injected i.v. with 2-deoxy-2-[ $\left[{ }^{18} \mathrm{~F}\right]$ fluoro-D-glucose $\left(\left[{ }^{18} \mathrm{~F}\right] \mathrm{FDG}, 6.7 \pm 1.0 \mathrm{MBq}\right.$ $(n=31))$. Forty minutes later, a second 20-min PET acquisition was performed. Blocking studies (carrier-added) were carried out in HCC827 $(n=9)$ and NCI-H1975 $(n=6)$ tumor-bearing mice, wherein erlotinib hydrochloride (OSI744, Selleck Chemicals) dissolved in $20 \%$ Captisol $^{\circledR}$ was injected at a dose equivalent to $6.4 \pm 0.4 \mathrm{mg} / \mathrm{kg}$ erlotinib, 3$10 \mathrm{~min}$ prior to the injection of $6-\mathrm{O}-\left[{ }^{18} \mathrm{~F}\right] \mathrm{FEE}$.

Image processing and reconstruction were carried out as previously described [20]. Tumors' volumes of interest (VOIs) were delineated manually, based on the fused PET (6-O- $\left[{ }^{18} \mathrm{~F}\right] \mathrm{FEE}$ or $\left.\left[{ }^{18} \mathrm{~F}\right] \mathrm{FDG}\right)$ and $\mathrm{CT}$ images, and the corresponding 6-O- $\left[{ }^{18} \mathrm{~F}\right] \mathrm{FEE}$ time-activity curves (TACs) were generated. Distribution of radioactivity was calculated and expressed in standardized uptake values (SUVs) as previously described [20].

\section{In Vivo Stability Assay}

See the description in the ESM.

\section{Statistics}

Statistical analysis was made using GraphPad Prism 5 software. Unless otherwise stated, data is expressed as mean \pm SD. Median inhibitory concentration $\left(\mathrm{IC}_{50}\right)$ values of 6-OFEE and erlotinib for cell growth inhibition of each cell line were compared using Student's $t$ test. Comparisons of 6-O$\left[{ }^{18} \mathrm{~F}\right] \mathrm{FEE}$ uptake in tumors, in imaging studies, were made using one-way ANOVA, followed by Dunnett's post hoc test, using $\mathrm{HCC} 827$ tumor-bearing mice as the control group. The level of significance was regularly set at $p<0.05$.

\section{Results}

\section{Synthesis of 6-O-Fluoroethylerlotinib Standard and $6-O-\left[{ }^{18}\right.$ F]Fluoroethylerlotinib}

6-O-FEE was obtained with $32.3 \%$ yield $(23 \mathrm{mg})$ and a purity higher than $99 \%$, as determined by analytical HPLC. The overall synthesis time of 6-O- $\left[{ }^{18} \mathrm{~F}\right] \mathrm{FEE}$ from the end of bombardment (EOB) was $110 \mathrm{~min}$, including purification and formulation ( $9 \%$ ethanol in saline). An average radioactivity of $10.9 \pm 5.6 \mathrm{GBq}(n=8)$ was obtained, with an average radiochemical yield of $5.7 \pm 3.2 \%$ and a mean molar activity of $146 \pm 49 \mathrm{GBq} / \mu \mathrm{mol}$, all decay-corrected (DC) to the EOB. Radiochemical purity was routinely greater than $99 \%$. Identification of $6-\mathrm{O}-\left[{ }^{18} \mathrm{~F}\right] \mathrm{FEE}$ was confirmed by a co-injection of unlabeled 6-O-FEE to the HPLC, having retention times of 10.6-10.9 min. The stability of $6-\mathrm{O}-\left[{ }^{18} \mathrm{~F}\right] \mathrm{FEE}$ in solution at room temperature was examined hourly for $4 \mathrm{~h}$ using radio-TLC and HPLC, and the compound remained stable throughout the examination period (Suppl. Fig. 3, ESM).

\section{Growth Inhibition of NSCLC Cell Lines In Vitro}

The anti-proliferative effects of 6-O-FEE and erlotinib were tested in vitro using four human NSCLC cell lines that harbor the prevailing EGFR variants identified in NSCLC patients. The $\mathrm{IC}_{50}$ values presented in Table 1 indicate that erlotinib and 6-O-FEE exhibited comparable potencies and selectivities towards $\mathrm{EGFR}_{\mathrm{m}}$ cell lines. Though the $\mathrm{IC}_{50}$ value of 6-O-FEE towards $\mathrm{HCC} 827$ cells was almost tenfold higher than that of erlotinib, the difference was not statistically significant, and both compounds demonstrated high inhibitory potencies towards this cell line, in the low (1-9) $\mathrm{nM}$ range. Both erlotinib and 6-O-FEE had $\mathrm{IC}_{50}$ values 2-3 orders of magnitude higher with respect to the TKI-resistant (NCI-H1975) and the TKI-insensitive (QG56) cell lines, compared to the TKI-sensitive (NCI-H3255 and HCC827) cells.

Imaging NSCLC Tumor-Bearing Mice Using 6-O$\left[{ }^{18} \mathrm{~F}\right] F E E$

The kinetics of radioactivity distribution was examined for $1 \mathrm{~h}$ following i.v. injection 6-O-[ $\left.{ }^{18} \mathrm{~F}\right] \mathrm{FEE}$ to NSCLC tumorbearing mice. The TACs presented in Fig. 3 demonstrate two to threefold higher radioactivity concentrations in HCC827 tumors, compared to those in NCI-H1975 and QG56 tumors, with mean SUVs of 1.0, 0.5, and 0.3, respectively, at $60 \mathrm{~min}$ after injection. Moreover, following its initial accumulation in the tumor tissue, the radioactivity was retained in HCC827 and NCI-H1975 tumors, whereas a slow decline in radioactivity concentration was measured in QG56 tumors.

To investigate whether the accumulation of radioactivity in HCC827 and NCI-H1975 tumors was specific, erlotinib was administered in excess $(6.4 \pm 0.4 \mathrm{mg} / \mathrm{kg}) 3-10 \mathrm{~min}$ prior to $6-\mathrm{O}-\left[{ }^{18} \mathrm{~F}\right] \mathrm{FEE}$ injection to tumor-bearing mice. As depicted in Fig. 4, pre-administration of erlotinib had resulted in an almost twofold reduction in $\mathrm{HCC} 827$ tumor uptake at $60 \mathrm{~min}$ after $6-\mathrm{O}-\left[{ }^{18} \mathrm{~F}\right] \mathrm{FEE}$ injection (mean SUVS of 1.04 and 0.55 ), albeit the difference was not statistically significant. In contrast to the reduced radioactivity uptake measured in HCC827 tumors after pre-administration of erlotinib in excess, radioactivity concentrations in NCIH1975 tumors had in fact increased after pre-injection of 
Table 1.. Anti-proliferative effect of 6-O-FEE and erlotinib in human NSCLC cell cultures

\begin{tabular}{llll}
\hline Cell line & Type of EGFR mutation & IC $_{50}$ of erlotinib $[\mu \mathrm{M}](n)$ & $\mathrm{IC}_{50}$ of 6-O-FEE $[\mu \mathrm{M}](n)$ \\
\hline QG56 & None (wt EGFR) & $12.6 \pm 5.7(4)$ & $14.4 \pm 4.6(3)$ \\
HCC827 & Activating (delE746-A750) & $0.001 \pm 0.001(3)$ & $0.009 \pm 0.009(4)$ \\
NCI-H3255 & Activating (L858R point mutation) & $0.05 \pm 0.03(3)$ & $0.03 \pm 0.04(3)$ \\
NCI-H1975 & Double (L858R + T790M) & $3.2 \pm 1.1(3)$ & $3.6 \pm 1.5(3)$ \\
\hline
\end{tabular}

non-labeled erlotinib, from a mean SUV of 0.5 to 0.7 at 60 min after 6-O- $\left[{ }^{18}\right.$ F]FEE injection (Fig. 4).

Representative PET-CT slice images following 6-O$\left[{ }^{18} \mathrm{~F}\right]$ FEE injection are illustrated in Fig. 5. Similar to the results obtained with $\left[{ }^{11} \mathrm{C}\right]$ erlotinib $[20,35]$, the predominant route of $6-\mathrm{O}-\left[{ }^{18} \mathrm{~F}\right] \mathrm{FEE}$ elimination was via hepatobiliary clearance.

\section{In Vivo Stability}

The metabolic fate of $6-\mathrm{O}-\left[{ }^{18} \mathrm{~F}\right] \mathrm{FEE}$ was studied 2,15 , and $30 \mathrm{~min}$ after its injection to BALB/c mice. To this end, mice were sacrificed at the allotted time points after injection, followed by collection of blood and urine samples and excision of the entire liver. The percentages of extracted radioactivity from the blood and the liver at each time point are illustrated in Fig. 6a, revealing consistent levels of $49 \pm$ $14 \%$ and $84 \pm 2 \%$ extraction from the blood and the liver, respectively, at the three studied time points. To evaluate the fraction of extracted radioactivity which could be attributed to $6-\mathrm{O}-\left[{ }^{18} \mathrm{~F}\right] \mathrm{FEE}$, the processed plasma, liver, and urine samples were loaded onto normal-phase TLC plates, and the radioactive bands were visualized using a phosphor screen. The radio-TLC plates presented in Fig. $6 \mathrm{~b}$ indicate that over $96 \%$ of the radioactivity present in plasma at all three time points represented the intact compound. Radioactive metabolites in liver samples could be detected already at $2 \mathrm{~min}$, representing about $2 \%$ of the extracted radioactivity. At later time points, the fraction of radioactive metabolites had further increased, and 6-O-[ $\left.{ }^{18} \mathrm{~F}\right] \mathrm{FEE}$ represented $80-85 \%$ of the extracted radioactivity in the liver. The presence of radioactive metabolites in urine sample could also be detected, although faintly, already at $2 \mathrm{~min}$ after injection. Several polar metabolites were apparent at the later time points, accounting for essentially all the radioactive signal in the urine.

\section{Discussion}

We have designed, synthetized, and investigated the fluorinated analogue of erlotinib, 6-O-FEE (Fig. 1). In vitro experiments using human NSCLC cell cultures indicated that similar to erlotinib, 6-O-FEE was 2-3 orders of magnitude more potent in inhibiting the proliferation of EGFR $_{m}$ cells (HCC827 and NCI-H3255) compared to those expressing the acquired $\mathrm{T} 790 \mathrm{M}$ resistance mutation (NCIH1975) or the wild-type (wt) receptor (QG56) (Table 1), suggesting that this analogue had maintained the increased affinity of erlotinib to the predominant sensitizing mutations of the EGFR [36].

Subsequently, 6-O-FEE was labeled with fluorine-18 via a two-step synthesis (Fig. 2) and administered to NSCLC tumorbearing mice with or without pre-injection of erlotinib in excess. The tumor TACs obtained following injection of 6-O$\left[{ }^{18} \mathrm{~F}\right] \mathrm{FEE}$ revealed 2- and 3.3-fold higher accumulation of radioactivity in HCC827 compared to NCI-H1975 and QG56 tumors, with mean SUVs of 1.0, 0.5, and 0.3, respectively, at 60 min after injection (Fig. 3). These results are in good agreement with those previously obtained with $\left[{ }^{11} \mathrm{C}\right]$ erlotinib, wherein a 3.5-fold higher accumulation of radioactivity was
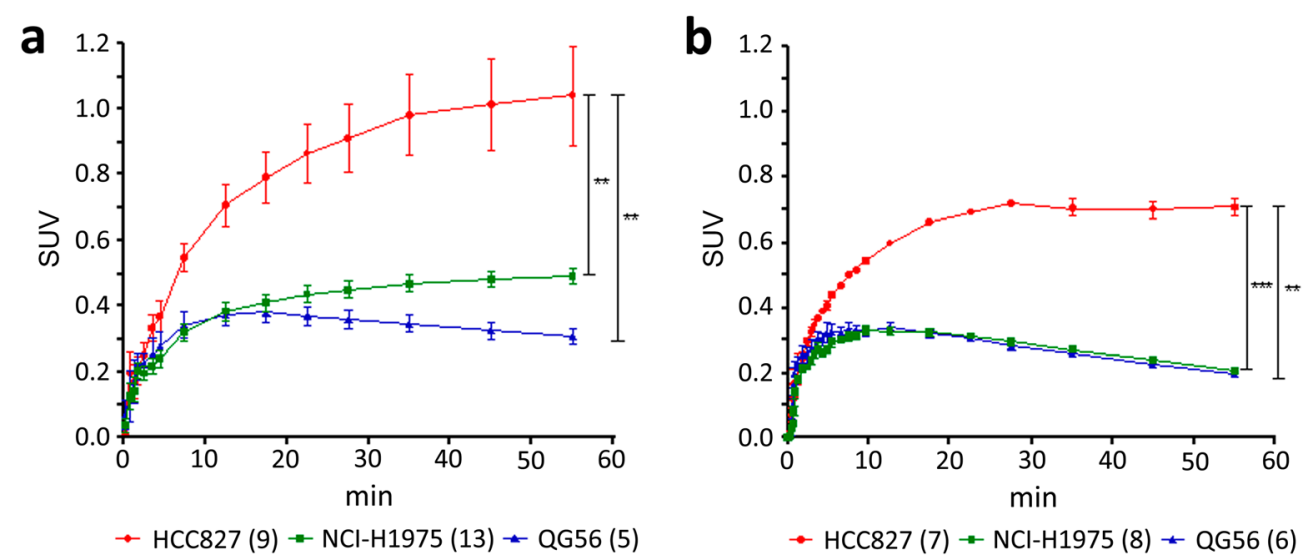

Fig. 3. Time-activity curves of $\mathbf{a} 6-\mathrm{O}-\left[{ }^{18} \mathrm{~F}\right] \mathrm{FEE}$ and $\mathbf{b}\left[{ }^{11} \mathrm{C}\right]$ erlotinib following their i.v. injection to NSCLC tumor-bearing mice. Results are presented as mean \pm SEM, and the number of animals per group is listed in brackets. ${ }^{\star \star} p<0.01$; ${ }^{\star \star \star} p<0.001$. 

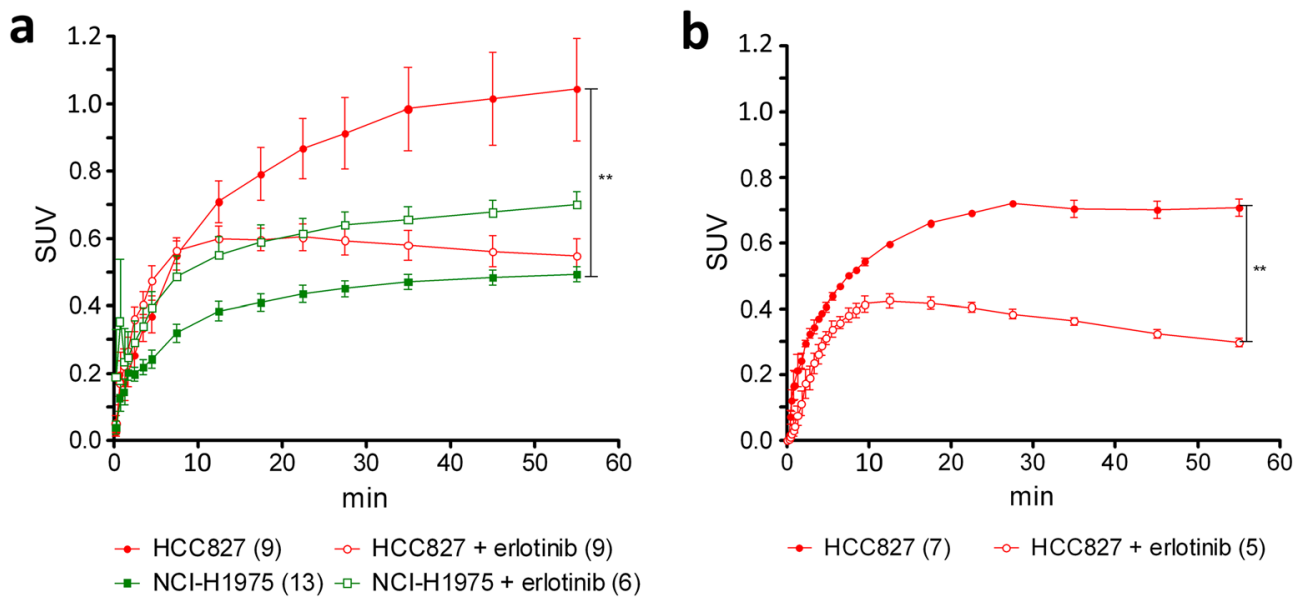

Fig. 4. Time-activity curves following i.v. injection of $\mathbf{a} 6-\mathrm{O}-\left[{ }^{18} \mathrm{~F}\right] \mathrm{FEE}$ and $\mathbf{b}\left[{ }^{11} \mathrm{C}\right]$ erlotinib to NSCLC tumor-bearing mice with and without pre-injection of non-labeled erlotinib $(6.4 \pm 0.4 \mathrm{mg} / \mathrm{kg})$. Results are presented as mean $\pm \mathrm{SEM}$, and the number of animals per group is listed in brackets. ${ }^{\star *} p<0.01$.

measured in $\mathrm{HCC} 827$ tumors (SUV $\cong 0.7)$ compared to NCIH1975 and QG56 (SUV $\cong 0.2)$, at the same time point (Fig. 3) [20]. Moreover, 6-O- $\left[{ }^{18} \mathrm{~F}\right] \mathrm{FEE}$ and $\left[{ }^{11} \mathrm{C}\right]$ erlotinib exhibited accumulation and retention of radioactivity in $\mathrm{HCC} 827$ $\left(E G F R_{m}\right)$ tumors, whereas a moderate washout of radioactivity from QG56 (wtEGFR) tumors was observed with time. Interestingly, however, the TACs of $6-\mathrm{O}-\left[{ }^{18} \mathrm{~F}\right] \mathrm{FEE}$ and $\left[{ }^{11} \mathrm{C}\right]$ erlotinib in NCI-H1975 tumors, which express both the p.L858R and the T790M mutation, presented different trends after the initial 10-min accumulation. Whereas $\left[{ }^{11} \mathrm{C}\right]$ erlotinib was progressively cleared from these tumors, radioactivity levels had gradually increased in NCI-H1975 tumors after the injection of 6-O- $\left[{ }^{18} \mathrm{~F}\right] \mathrm{FEE}$.

To evaluate the extent of specific binding, erlotinib $(6.4 \mathrm{mg} / \mathrm{kg})$ was administered $3-10 \mathrm{~min}$ prior to the injection of 6-O- $\left[{ }^{18} \mathrm{~F}\right] \mathrm{FEE}$ into HCC827 and NCI-H1975 tumorbearing mice. As illustrated in Fig. 4, HCC827 SUV at 60 min had dropped by almost twofold compared to baseline (1.04 vs. 0.55), indicative of specific binding of 6-O$\left.{ }^{18} \mathrm{~F}\right] \mathrm{FEE}$ to the EGFR. Conversely, radioactivity levels measured in NCI-H1975 tumors were consistently higher with the administration of non-labeled erlotinib than
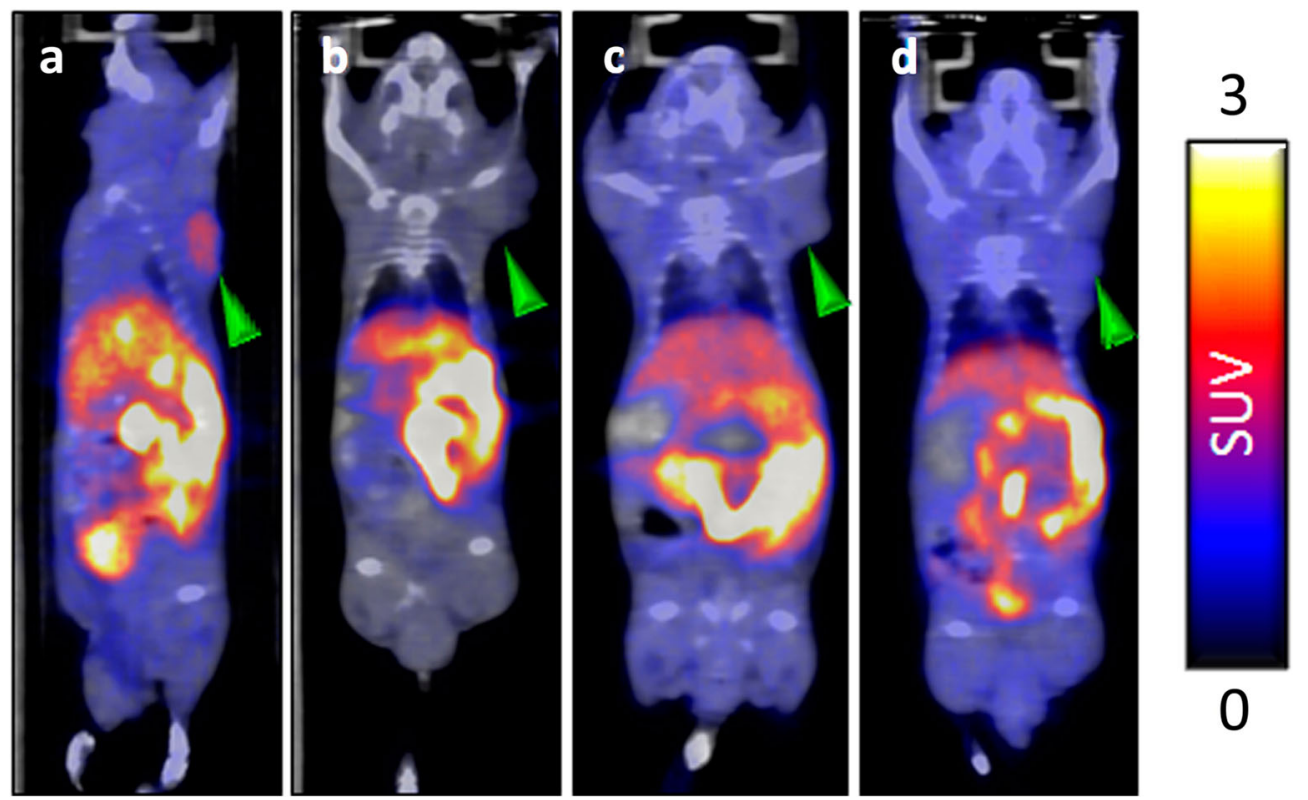

Fig. 5. Representative PET-CT coronal slice images following injection of 6-O- $\left[{ }^{18} \mathrm{~F}\right] \mathrm{FEE}$ into a HCC827, b QG56, and $\mathbf{c} \mathrm{NCl}-$ H1975 tumor-bearing mice. d Mouse is the same HCC827 tumor-bearing mouse presented in a, after pre-injection of nonlabeled erlotinib $(6.8 \mathrm{mg} / \mathrm{kg})$. Tumors are indicated by the green arrowheads. Images are normalized to the same color scale and represent the summation of $30-60$ min after $6-0-\left[{ }^{18} \mathrm{~F}\right] \mathrm{FEE}$ injection. 

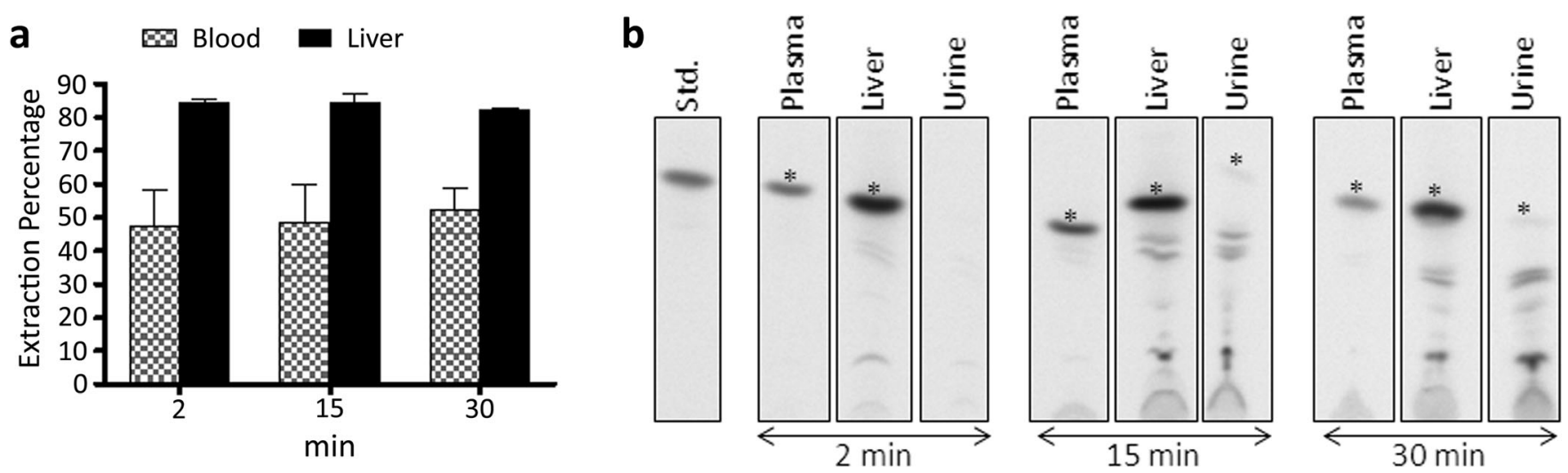

Fig. 6. a Extraction fractions of radioactivity from blood and liver samples following injection of $6-\mathrm{O}-\left[{ }^{18} \mathrm{~F}\right] \mathrm{FEE}$ into BALB/c mice. b Representative radio-TLC images obtained after loading $6-\mathrm{O}-\left[{ }^{18} \mathrm{~F}\right] \mathrm{FEE}$ standard (Std.), plasma, liver, and urine samples obtained at 2, 15, and 30 min after 6-O- $\left[{ }^{18} \mathrm{~F}\right] \mathrm{FEE}$ injection. The band representing 6-O- $\left[{ }^{18} \mathrm{~F}\right] \mathrm{FEE}$ in each sample is marked with an asterisk. Results are presented as mean \pm SEM.

without. This suggested that the accumulation of 6-O$\left[{ }^{18} \mathrm{~F}\right] \mathrm{FEE}$ in NCI-H1975 tumors was principally nonspecific and the higher radioactivity concentrations measured in NCI-H1975 tumors after administration of erlotinib in excess could most likely be attributed to the resulting higher radioactivity levels in blood, such as those reported for $\left[{ }^{11} \mathrm{C}\right]$ erlotinib after the administration of non-labeled erlotinib in excess [32]. It should be noted that in our previous blocking studies, $\left[{ }^{11} \mathrm{C}\right]$ erlotinib was co-injected with erlotinib $(6.7 \mathrm{mg} / \mathrm{kg})$ [20], whereas in the present study, erlotinib was administered several minutes before the injection of 6-O- $\left[{ }^{18} \mathrm{~F}\right] \mathrm{FEE}$, leading to the higher apparent radioactivity levels in $\mathrm{HCC} 827$ tumors during the first $5 \mathrm{~min}$ of the blocking experiment, compared to baseline (Fig. 4).

Since the presence of radioactive metabolites might also affect the measured SUVs and the extent of specific binding, the metabolic fate of $6-\mathrm{O}-\left[{ }^{18} \mathrm{~F}\right] \mathrm{FEE}$ was investigated up to $30 \mathrm{~min}$ following its injection to mice. During this time, over $96 \%$ of the radioactivity in plasma could be attributed to the intact compound, whereas radioactive metabolites were detected only in liver and urine samples, accounting for $15-20 \%$ and $100 \%$ of the radioactivity, respectively. Thus, the radioactive signal measured in NCI-H1975 tumors most likely results from non-specific binding of $6-\mathrm{O}-\left[{ }^{18} \mathrm{~F}\right] \mathrm{FEE}$, though it remains to be answered why, unlike in QG56 tumors, no washout of radioactivity from these tumors was observed with time. It is yet possible that part of 6-O$\left[{ }^{18} \mathrm{~F}\right]$ FEE's binding to NCI-H1975 tumors is specific, but cannot be blocked with erlotinib. The two compounds could potentially exhibit different binding characteristics, such that 6-O- $\left[{ }^{18}\right.$ F]FEE accumulation would be reduced after preadministration of 6-O-FEE in excess, but not after erlotinib administration. This issue remains to be addressed in future studies.

Most patients with $\mathrm{EGFR}_{\mathrm{m}}$ tumors become resistant to erlotinib, gefitinib, or afatinib, with a PFS of 10-13 months. The EGFR T790M mutation, which is associated with acquired resistance to first- and second-line EGFR TKIs, has been reported in about $60 \%$ of patients with disease progression after initial response to EGFR TKI therapy [6]. Such patients can still be treated with osimertinib, a thirdgeneration irreversible EGFR TKI with activity against $\mathrm{EGFR}_{\mathrm{m}}{ }^{-}$and T790M-expressing NSCLC [37], which has also been recently approved for first-line treatment of EGFR $_{\mathrm{m}}$ NSCLC [12]. Thus, the genetically diverse and dynamic molecular profile of NSCLC requires periodic monitoring for continuous optimization of therapy. Since not all patients with advanced NSCLC are suitable for (repeat) biopsy, alternative non-invasive approaches for examining EGFR's molecular status have been investigated, mostly focusing on liquid biopsies, such as circulating-free tumor DNA (ctDNA) and circulating tumor cells (CTCs). While the analysis of these circulating biomarkers from peripheral blood can potentially reveal spatial and temporal heterogeneity of tumors in real time, the paucity of tumorassociated markers with respect to other components in blood requires highly sensitive and specific isolation and detection technologies [38], posing a challenge on the clinical application of liquid biopsies. Although certain challenges concerning the clinical use of liquid biopsies remain, the cobas ${ }^{\circledR}$ EGFR Mutation Test v2 for analyzing ctDNA from plasma specimens of NSCLC patients has gained FDA approval in 2016, as a companion diagnostic test for identifying $E_{G F R}$ NSCLC patients eligible for treatment with EGFR-targeted TKIs (https://www.fda.gov/ drugs/informationondrugs/approveddrugs/ucm504540). Furthermore, in their recent guidelines, the College of American Pathologists, the International Association for the Study of Lung Cancer, and the Association for Molecular Pathology presented an expert consensus opinion supporting the use of ctDNA to identify T790M mutations in patients with progression or secondary resistance to EGFR-targeted TKIs [39].

Going forward, several questions remain to be addressed with respect to $6-\mathrm{O}-\left[{ }^{18} \mathrm{~F}\right] \mathrm{FEE}$, including its sensitivity and specificity in detecting the common activating mutations, as 
well as uncommon EGFR mutations, which are found in about $10 \%$ of NSCLC patients [7, 14] and resistance mutations, such as the secondary T790M mutation, MET amplification, or phenotype transformation. Interestingly, while our previously obtained results with $\left[{ }^{11} \mathrm{C}\right]$ erlotinib suggest that tumors expressing the L858R and T790M mutations could be differentiated from those expressing the 746-750 (exon 19) ELREA deletion mutation or the L858R point mutation [20], Traxl and colleagues reported that the calculated distribution volume $\left(\mathrm{V}_{\mathrm{T}}\right)$ of $\left[{ }^{11} \mathrm{C}\right]$ erlotinib in NSCLC xenografts harboring an exon 19 deletion mutation was not different from those of resistant cells also expressing the T790M mutation or MET amplification [32]. In the current study, 6-O- $\left[{ }^{18} \mathrm{~F}\right] \mathrm{FEE}$ could discriminate NSCLC xenografts with an EGFR $_{\mathrm{m}}$ exon 19 deletion mutation from those bearing the wt receptor or a double-mutant (L858R + $\mathrm{T} 790 \mathrm{M})$ receptor. Its potential contribution to the precise molecular characterization of EGFR status in NSCLCs remains to be further investigated, particularly as a complementary diagnostic tool, e.g., in cases of discordant results between tissue and liquid biopsies.

Finally, the semi-quantitative approach taken in the present study to analyze differences in tumor uptake may reflect only part of the full potential of 6-O- $\left[{ }^{18} \mathrm{~F}\right] \mathrm{FEE}$ in discriminating and characterizing the mutational status of EGFR in NSCLCs. On the other end of the analytical scale, as the field of radiomics is increasingly applied in medical imaging [19], the radiomic PET signature of $6-\mathrm{O}-\left[{ }^{18} \mathrm{~F}\right] \mathrm{FEE}$ could provide incremental value, rendering $6-\mathrm{O}-\left[{ }^{18} \mathrm{~F}\right] \mathrm{FEE}$ PET a useful surrogate and/or complementary screening tool for the stratification of NSCLC patients prior to and during EGFR TKI treatment and improving medical decisionmaking.

\section{Conclusion}

The fluorinated erlotinib analogue, 6-O-FEE, displays potency and selectivity characteristics towards various forms of the EGFR, which are similar to those of erlotinib. The results obtained following injection of $6-\mathrm{O}-\left[{ }^{18} \mathrm{~F}\right] \mathrm{FEE}$ to NSCLC tumor-bearing mice illustrate that this radiopharmaceutical is capable of differentiating tumors harboring the wt receptor from those expressing an exon 19 deletion mutation or the double L858R + T790M mutations, warranting further clinical studies to characterize the full potential of this compound for PET MI of the EGFR in NSCLC patients.

Acknowledgements. The authors wish to thank the Cyclotron/ Radiochemistry Unit's staff and Eng. Sassy Cohen in particular for their excellent technical support and assistance and the National Cancer Institute - the Division of Cancer Treatment and Diagnosis, Frederick, MD, USA, for providing the NCI-H3255 cell line.

Compliance with Ethical Standards. All animal studies were conducted under protocol number MD-13-13833-5, approved by the Animal Research Ethics Committee of the Hebrew University of Jerusalem, and in accordance with its guidelines.

\section{Conflict of Interest}

The authors declare that they have no conflict of interest.

Open Access This article is distributed under the terms of the Creative Commons Attribution 4.0 International License (http:// creativecommons.org/licenses/by/4.0/), which permits unrestricted use, distribution, and reproduction in any medium, provided you give appropriate credit to the original author(s) and the source, provide a link to the Creative Commons license, and indicate if changes were made.

\section{References}

1. Zhao D, Chen X, Qin N, Su D, Zhou L, Zhang Q, Li X, Zhang X, Jin M, Wang J (2017) The prognostic role of EGFR-TKIs for patients with advanced non-small cell lung cancer. Sci Rep 7:40374

2. Han SW, Kim TY, Hwang PG, Jeong S, Kim J, Choi IS, Oh DY, Kim JH, Kim DW, Chung DH, Im SA, Kim YT, Lee JS, Heo DS, Bang YJ, Kim NK (2005) Predictive and prognostic impact of epidermal growth factor receptor mutation in non-small-cell lung cancer patients treated with gefitinib. J Clin Oncol 23:2493-2501

3. Eberhard DA, Johnson BE, Amler LC, Goddard AD, Heldens SL, Herbst RS, Ince WL, Jänne PA, Januario T, Johnson DH, Klein P, Miller VA, Ostland MA, Ramies DA, Sebisanovic D, Stinson JA, Zhang YR, Seshagiri S, Hillan KJ (2005) Mutations in the epidermal growth factor receptor and in KRAS are predictive and prognostic indicators in patients with non-small-cell lung cancer treated with chemotherapy alone and in combination with erlotinib. J Clin Oncol 23:5900-5909

4. Mok T, Wu YL, Lee JS, Yu CJ, Sriuranpong V, Sandoval-Tan J, Ladrera G, Thongprasert S, Srimuninnimit V, Liao M, Zhu Y, Zhou C, Fuerte F, Margono B, Wen W, Tsai J, Truman M, Klughammer B, Shames DS, Wu L (2015) Detection and dynamic changes of EGFR mutations from circulating tumor DNA as a predictor of survival outcomes in NSCLC patients treated with first-line intercalated erlotinib and chemotherapy. Clin Cancer Res 21:3196-3203

5. Peled N, Roisman LC, Miron B, Pfeffer R, Lanman RB, Ilouze M, Dvir A, Soussan-Gutman L, Barlesi F, Tarcic G, Edelheit O, Gandara D, Elkabetz Y (2017) Subclonal therapy by two EGFR TKIs guided by sequential plasma cell-free DNA in EGFR-mutated lung cancer. $J$ Thorac Oncol 12:e81-e84

6. (2017) NCCN Clinical Practice Guidelines in Oncology: https:// www.nccn.org/professionals/physician_gls/default.aspx

7. Tan DS, Yom SS, Tsao MS et al (2016) The International Association for the Study of Lung Cancer Consensus Statement on Optimizing Management of EGFR Mutation-Positive Non-Small Cell Lung Cancer: status in 2016. J Thorac Oncol 11:946-963

8. Hirsch FR, Bunn PA Jr (2009) EGFR testing in lung cancer is ready for prime time. Lancet Oncol 10:432-433

9. Zhang YL, Yuan JQ, Wang KF, Fu XH, Han XR, Threapleton D, Yang ZY, Mao C, Tang JL (2016) The prevalence of EGFR mutation in patients with non-small cell lung cancer: a systematic review and meta-analysis. Oncotarget 7:78985-78993

10. Hanna N, Johnson D, Temin S, Baker S Jr, Brahmer J, Ellis PM, Giaccone G, Hesketh PJ, Jaiyesimi I, Leighl NB, Riely GJ, Schiller JH, Schneider BJ, Smith TJ, Tashbar J, Biermann WA, Masters G (2017) Systemic therapy for stage IV non-small-cell lung cancer: American Society of Clinical Oncology clinical practice guideline update. J Clin Oncol 35:3484-3515

11. Keedy VL, Temin S, Somerfield MR, Beasley MB, Johnson DH, McShane LM, Milton DT, Strawn JR, Wakelee HA, Giaccone G (2011) American Society of Clinical Oncology provisional clinical opinion: epidermal growth factor receptor (EGFR) mutation testing for patients with advanced non-small-cell lung cancer considering firstline EGFR tyrosine kinase inhibitor therapy. J Clin Oncol 29:21212127

12. US FDA approves TAGRISSO ${ }^{\circ}$ (osimertinib) as 1st-line treatment for EGFR-mutated non-small cell lung cancer. https:// www.astrazeneca.com/investor-relations/Stock-exchange-announcements/us-fda-approves-tagrisso-as-1 st-line-treatment-for-egfr-mutatednon-small-cell-lung-cancer-19042018.html 
13. Assi HI, Kamphorst AO, Moukalled NM, Ramalingam SS (2018) Immune checkpoint inhibitors in advanced non-small cell lung cancer. Cancer 124:248-261

14. Lindeman NI, Cagle PT, Beasley MB, Chitale DA, Dacic S, Giaccone G, Jenkins RB, Kwiatkowski DJ, Saldivar JS, Squire J, Thunnissen E, Ladanyi M (2013) Molecular testing guideline for selection of lung cancer patients for EGFR and ALK tyrosine kinase inhibitors: guideline from the College of American Pathologists, International Association for the Study of Lung Cancer, and Association for Molecular Pathology. J Thorac Oncol 8:823-859

15. Kris MG, Johnson BE, Berry LD, Kwiatkowski DJ, Iafrate AJ, Wistuba II, Varella-Garcia M, Franklin WA, Aronson SL, Su PF, Shyr Y, Camidge DR, Sequist LV, Glisson BS, Khuri FR, Garon EB, Pao W, Rudin C, Schiller J, Haura EB, Socinski M, Shirai K, Chen H, Giaccone G, Ladanyi M, Kugler K, Minna JD, Bunn PA (2014) Using multiplexed assays of oncogenic drivers in lung cancers to select targeted drugs. JAMA 311:1998-2006

16. Arcila ME, Oxnard GR, Nafa K, Riely GJ, Solomon SB, Zakowski MF, Kris MG, Pao W, Miller VA, Ladanyi M (2011) Rebiopsy of lung cancer patients with acquired resistance to EGFR inhibitors and enhanced detection of the T790M mutation using a locked nucleic acid-based assay. Clin Cancer Res 17:1169-1180

17. Rachiglio AM, Esposito Abate R, Sacco A, Pasquale R, Fenizia F, Lambiase M, Morabito A, Montanino A, Rocco G, Romano C, Nappi A, Iaffaioli RV, Tatangelo F, Botti G, Ciardiello F, Maiello MR, de Luca A, Normanno N (2016) Limits and potential of targeted sequencing analysis of liquid biopsy in patients with lung and colon carcinoma. Oncotarget 7:66595-66605

18. Sacher AG, Paweletz C, Dahlberg SE, Alden RS, O'Connell A, Feeney N, Mach SL, Jänne PA, Oxnard GR (2016) Prospective validation of rapid plasma genotyping for the detection of EGFR and KRAS mutations in advanced lung cancer. JAMA Oncol 2:1014-1022

19. Liu Y, Kim J, Balagurunathan Y et al (2016) Radiomic features are associated with EGFR mutation status in lung adenocarcinomas. Clin Lung Cancer 17:441-448 e446

20. Abourbeh G, Itamar B, Salnikov O et al (2015) Identifying erlotinibsensitive non-small cell lung carcinoma tumors in mice using $\left[{ }^{11}\right.$ C]erlotinib PET. EJNMMI Res 5:4. https://doi.org/10.1186/ s13550-014-0080-0

21. Slobbe P, Windhorst AD, Stigter-van Walsum M et al (2015) A comparative PET imaging study with the reversible and irreversible EGFR tyrosine kinase inhibitors $\left[{ }^{11} \mathrm{C}\right]$ erlotinib and $\left[{ }^{18} \mathrm{~F}\right]$ afatinib in lung cancer-bearing mice. EJNMMI Res 5:14. https://doi.org/10.1186/ s13550-015-0088-0

22. Huang S, Han Y, Chen M, Hu K, Qi Y, Sun P, Wang M, Wu H, Li G, Wang Q, du Z, Zhang K, Zhao S, Zheng X (2018) Radiosynthesis and biological evaluation of ${ }^{18} \mathrm{~F}$-labeled 4-anilinoquinazoline derivative $\left({ }^{18}\right.$ F-FEA-Erlotinib) as a potential EGFR PET agent. Bioorg Med Chem Lett 28:1143-1148

23. Jain A, Kameswaran M, Pandey U, Prabhash K, Sarma HD, Dash A (2017) ${ }^{68} \mathrm{Ga}$ labeled Erlotinib: a novel PET probe for imaging EGFR over-expressing tumors. Bioorg Med Chem Lett 27:4552-4557

24. Fenizia F, De Luca A, Pasquale R et al (2015) EGFR mutations in lung cancer: from tissue testing to liquid biopsy. Future Oncol 11:1611-1623

25. Slobbe P, Poot AJ, Windhorst AD, van Dongen GAMS (2012) PET imaging with small-molecule tyrosine kinase inhibitors: TKI-PET. Drug Discov Today 17:1175-1187

26. van Dongen GA, Poot AJ, Vugts DJ (2012) PET imaging with radiolabeled antibodies and tyrosine kinase inhibitors: immuno-PET and TKI-PET. Tumour Biol 33:607-615
27. Bahce I, Yaqub M, Errami H et al (2016) Effects of erlotinib therapy on $\left[{ }^{11}\right.$ C $]$ erlotinib uptake in EGFR mutated, advanced NSCLC. EJNMMI Res 6:10. https://doi.org/10.1186/s13550-016-0169-8

28. Memon AA, Weber B, Winterdahl M, Jakobsen S, Meldgaard P, Madsen HHT, Keiding S, Nexo E, Sorensen BS (2011) PET imaging of patients with non-small cell lung cancer employing an EGF receptor targeting drug as tracer. Br J Cancer 105:1850-1855

29. Petrulli JR, Sullivan JM, Zheng M-Q, Bennett DC, Charest J, Huang Y, Morris ED, Contessa JN (2013) Quantitative analysis of $\left[{ }^{11} \mathrm{C}\right]-$ erlotinib PET demonstrates specific binding for activating mutations of the EGFR kinase domain. Neoplasia 15:1347-1353

30. Weber B, Winterdahl M, Memon A, Sorensen BS, Keiding S, Sorensen L, Nexo E, Meldgaard P (2011) Erlotinib accumulation in brain metastases from non-small cell lung cancer: visualization by positron emission tomography in a patient harboring a mutation in the epidermal growth factor receptor. J Thorac Oncol 6:1287-1289

31. Bahce I, Smit EF, Lubberink M, van der Veldt AAM, Yaqub M, Windhorst AD, Schuit RC, Thunnissen E, Heideman DAM, Postmus PE, Lammertsma AA, Hendrikse NH (2013) Development of $\left[{ }^{11} \mathrm{C}\right]$ erlotinib positron emission tomography for in vivo evaluation of EGF receptor mutational status. Clin Cancer Res 19:183-193

32. Traxl A, Beikbaghban T, Wanek T, Kryeziu K, Pirker C, Mairinger S, Stanek J, Filip T, Sauberer M, Kuntner C, Berger W, Langer O (2017) $\left[{ }^{11} \mathrm{C}\right]$ Erlotinib PET cannot detect acquired erlotinib resistance in NSCLC tumor xenografts in mice. Nucl Med Biol 52:7-15

33. Rodnick ME, Brooks AF, Hockley BG, Henderson BD, Scott PJH (2013) A fully-automated one-pot synthesis of $\left[{ }^{18} \mathrm{~F}\right]$ fluoromethylcholine with reduced dimethylaminoethanol contamination via $\left[{ }^{18} \mathrm{~F}\right]$ fluoromethyl tosylate. Appl Radiat Isot 78:26-32

34. Dent MF, Hubbold L, Radford H, Wilson AP (1995) The methylene blue colorimetric microassay for determining cell line response to growth factors. Cytotechnology 17:27-33

35. Petrulli JR, Hansen SB, Abourbeh G, Yaqub M, Bahce I, Holden D, Huang Y, Nabulsi NB, Contessa JN, Mishani E, Lammertsma AA, Morris ED (2017) A multi species evaluation of the radiation dosimetry of $\left[{ }^{11} \mathrm{C}\right]$ erlotinib, the radiolabeled analog of a clinically utilized tyrosine kinase inhibitor. Nucl Med Biol 47:56-61

36. Carey KD, Garton AJ, Romero MS, Kahler J, Thomson S, Ross S, Park F, Haley JD, Gibson N, Sliwkowski MX (2006) Kinetic analysis of epidermal growth factor receptor somatic mutant proteins shows increased sensitivity to the epidermal growth factor receptor tyrosine kinase inhibitor, erlotinib. Cancer Res 66:8163-8171

37. Passaro A, Guerini-Rocco E, Pochesci A, Vacirca D, Spitaleri G, Catania CM, Rappa A, Barberis M, de Marinis F (2017) Targeting EGFR T790M mutation in NSCLC: from biology to evaluation and treatment. Pharmacol Res 117:406-415

38. Lim M, Kim CJ, Sunkara V, Kim MH, Cho YK (2018) Liquid biopsy in lung cancer: clinical applications of circulating biomarkers (CTCs and ctDNA). Micromachines 9. https://doi.org/10.3390/mi9030100

39. Lindeman NI, Cagle PT, Aisner DL, Arcila ME, Beasley MB, Bernicker EH, Colasacco C, Dacic S, Hirsch FR, Kerr K, Kwiatkowski DJ, Ladanyi M, Nowak JA, Sholl L, Temple-Smolkin R, Solomon B, Souter LH, Thunnissen E, Tsao MS, Ventura CB, Wynes MW, Yatabe Y (2018) Updated molecular testing guideline for the selection of lung cancer patients for treatment with targeted tyrosine kinase inhibitors: guideline from the College of American Pathologists, the International Association for the Study of Lung Cancer, and the Association for Molecular Pathology. Arch Pathol Lab Med 142:321-346

40. Mock BH, Winkle W, Vavrek MT (1997) A color spot test for the detection of Kryptofix 2.2.2 in $\left[{ }^{18} \mathrm{~F}\right]$ FDG preparations. Nucl Med Biol 24:193-195 